\title{
Investigating the Relationship Between Insulin Perceptions and Diabetes Self-Management of Intensive Care Patients with Type 2 Diabetes
}

\section{Yoğun Bakıma Yatan Tip 2 Diyabetli Hastaların İnsüline Karşı Algıları ile Diyabet Öz Yönetimleri Arasındaki İlişkinin İncelenmesi}

\author{
(D)Elif Günay İsmailoğlu', @Serkan Timuçin² \\ I'zmir Bakircay University, Faculty of Health Sciences Department of Nursing, Izmir, Turkey \\ 2Izmir Bakircay University Graduate Education Institute Fundamentals of Nursing Masters Program with Thesis, Izmir, Turkey
}

\begin{abstract}
Aim: This study aimed to determine the level of perception of insulin and diabetes symptom management of patients with Type 2 diabetes who received inpatient treatment in intensive care.

Material and Method: This descriptive study was conducted in the Internal Medicine and Anesthesia Intensive Care units of a state hospital during the period of December 01, 2020 and March 31, 2021. The sample of the study was composed of 100 voluntary patients who used insulin. Research data were collected via the Patient Introduction Form, Diabetes Self-Management Questionnaire and the Insulin Treatment Appraisal Scale. Written permission was obtained from ethics committee and patients. The data analysis consisted of arithmetic mean, number, percentage, Spearman's Correlation, Mann Whitney U and Kruskal Wallis tests.

Results: The average age of the patients was $44.57 \pm 14.8,52 \%$ were female, $72 \%$ were single. The mean duration of insulin use was $2.8 \pm 1.17$ years. Patients' Insulin Treatment Appraisal positive and negative item subscale mean scores were $12.56 \pm 3.43$ and $48.18 \pm 12.09$, respectively. Patients' mean Diabetes Self-Management Questionnaire total score was 4.07 \pm 1.74 (range: $0.62-8.75$ ). There was a significant difference between the marital status, education level, existence of chronic disease and complications, regular use of insulin and Diabetes Self-Management Questionnaire and Insulin Treatment Appraisal Scale scores.

Conclusion: Patients have a high negative perception towards insulin use and their diabetes self-management is below the average. There was a high level of negative correlation between patients' negative insulin perception and glucose management and diet control sub-dimensions of their diabetes self-management. Accordingly, it is recommended to plan individual or group trainings in order to raise awareness about diabetes self management and patients' insulin treatment.
\end{abstract}

Keywords: Insulin Perceptions, Self-Management, Type 2 Diabetes Mellitus
Öz

Amaç: Bu çalışma ile yoğun bakımda yatarak tedavi gören Tip 2 diyabet hastalarının insüline karşı algıları ve diyabet semptom yönetim düzeyinin belirlenmesi sağlanacaktır.

Gereç ve Yöntem: Tanımlayıcı olan bu çalışma 1 Aralık 2020 ve 31 Mart 2021 tarihleri arasında bir devlet hastanesinin Dahiliye ve Anestezi Yoğun Bakım ünitelerinde gerçekleştirilmiştir. Çalışmanın örneklemini insülin kullanan 100 gönüllü hasta oluşturmuştur. Araştırma verileri Hasta Tanıtım Formu, İnsülin Tedavisi Değerlendirme Ölçeği ve Diyabet Öz Yönetim Skalası ile toplandı. Araştırmanın etik kurul izni ve hastalardan yazılı izin alındı. Verilerin analizi, aritmetik ortalama, sayı, yüzde, korelasyon, Mann Whitney U ve Kruskal- Wallis testleri kullanılarak yapıldı.

Bulgular: Hastaların yaş ortalaması 44,57 14,8 olup, \%52'si kadındır. Hastaların insülin kullanma yıl ortalaması 2.8 \pm 1.17 yıldır. Hastaların Diyabet Öz Yönetim

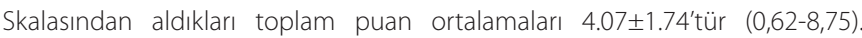
Hastaların Insülin Tedavisi Değerlendirme Ölçeği pozitif ve negatif madde alt boyutu puan ortalamaları sırasıyla $12.56 \pm 3.43 ; 48.18 \pm 12.09$ 'dur. Hastaların medeni durumu, eğitim düzeyi, kronik hastalık ve komplikasyon varlığı, düzenli insülin kullanımı ile Diyabet Öz Yönetim Skalası ve İnsülin Tedavisi Değerlendirme Ölçeği puan ortalamaları arasında anlamlı bir fark olduğu saptand.

Sonuç: Insülin kullanan Tip 2 diyabetli hastaların insülin kullanımına karşı negatif algısının fazla olduğu ve diyabet öz yönetimlerinin ortalamanın altında olduğu bulunmuştur. Hastaların negatif insülin algısı ile diyabet öz yönetiminin glikoz yönetimi ve diyet kontrolü alt boyutları arasında yüksek düzeyde negatif ilişki bulunmuştur. Hastaların diyabet öz yönetimi ve insülin tedavisine yönelik farkındalık oluşturulması amacıyla bireysel veya grup eğitimlerinin planlanmas önerilmektedir.

Anahtar Kelimeler: İnsülin Algısı, Öz Yönetim, Tip 2 Diyabet

Corresponding (illetişim): Elif GÜNAY ISMAiLOĞLU, Izmir Bakircay University, Faculty of Health Sciences, Department of Fundamentals of Nursing Menemen/IZMIR/TURKEY

E-mail (E-posta): elif.ismailoglu@bakircay.edu.tr

Received (Geliș Tarihi): 19.03.2021Ａccepted (Kabul Tarihi): 01.12 .2021 


\section{INTRODUCTION}

Type 2 Diabetes Mellitus (T2DM), which accounts for approximately $90 \%$ of all diabetics, is a metabolic syndrome characterized by hyperglycemia as a result of insulin resistance and impaired insulin secretion. ${ }^{[1-3]}$ The incidence of T2DM is gradually increasing due to obesity and sedentary life. According to the International Diabetes Federation Diabetes Atlas 2019 data; the estimated number of diabetic patients in the world is approximately 463 million and this number will reach 700 million by 2045 . Based on these data, Turkey is expected to be among the top 10 countries with the highest number of people with diabetes in the year 2045. ${ }^{[1,4]}$

When diabetes is not controlled, it causes complications in many parts of the body, leading to frequent hospitalizations and premature death. According to IDF (International Diabetes Federation) data, approximately 4.2 million adults between the ages of 20-79 died due to diabetes and its complications in 2019. [1] The worldwide increase in diabetes mellitus and the related complications such as hypoglycemia, diabetic ketoacidosis, retinopathy, nephropathy, neuropathy and diabetic foot show the importance of diabetes self-management. Self management in diabetes includes the self-care behaviors that ensure compliance with the use of medication, medical nutrition therapy, and physical activity. Individuals with diabetes should have knowledge and acquire self-care skills to ensure selfmanagement. ${ }^{[5]}$ It is imperative to transform self-management skills into a lifestyle to keep uncontrollable blood glucose, which is the main problem in individuals with diabetes, within normal limits and to prevent father complications. ${ }^{[6]}$ Learning self-care skills will facilitate their adaptation to treatment by providing them with the skills to cope with the disease and getting more satisfaction from life. ${ }^{[6,7]}$

Insulin is reported as the most effective treatment method in the treatment of hyperglycemia. ${ }^{\left[{ }^{[3}\right.}$ Studies have shown that insulin therapy is effective in slowing down the development and progression of chronic complications of diabetes. ${ }^{[9,10]}$ More than half of patients with type 2 diabetes need insulin therapy after 5 years. Despite the importance of insulin therapy, many patients with type 2 diabetes are unwilling or afraid of insulin therapy. This negative perception of insulin therapy is called "psychological insulin resistance".[11,12] Studies have reported that approximately $40-70 \%$ of patients with type 2 diabetes refuse insulin therapy. ${ }^{[12,13]}$ Patients may be resistant to insulin use due to reasons such as pain, hypoglycemia, accelerated weight gain, feelings of inadequacy and ineffectiveness in individuals as a result of decreased independence, and feelings of embarrassment in the community related to using insülin. ${ }^{[14-16]}$

The sooner diabetes management training is initiated, the lower will be the rate of complications and associated mortality. It has been observed that diabetic patients spend their lives more comfortably, acquire self-efficacy and enjoy a higher quality of life with successful symptom management. ${ }^{[17-}$

${ }^{19]}$ Also, the literature reports that it is necessary to evaluate the negative and positive perceptions of individuals with T2DM about insulin treatment before or after starting treatment. ${ }^{[5,20]}$ Evaluating the perceptions of diabetic patients will facilitate the planning of effective interventions for symptom management and behavioral change. This study aimed to determine the level of diabetes symptom management of patients with T2DM who received inpatient treatment in intensive care. In addition, the study explored the relationship between patients' insulin perceptions and their diabetes self-management.

\section{MATERIAL AND METHOD}

This study was conducted in the Internal Medicine and Anesthesia Intensive Care units of a state hospital during the period of December 01, 2020 and March 31, 2021. The study universe consisted of the patients hospitalized with the diagnosis of T2DM in the mentioned clinics of the hospital $(\mathrm{N}=150)$. The sample of the study was composed of 100 voluntary patients who had sufficient awareness to answer questionnaire and scale questions and who used insulin.

\section{Data Collection}

Written consent was obtained from the patients who volunteered to participate in the study by having them sign the informed consent form. The patients who gave written consent were asked to fill out the Patient Introduction Form, Diabetes Self-Management Questionnaire (DSMQ) and Insulin Treatment Appraisal Scale (ITAS).

Patient Introduction Form: In form has a total of 13 questions about patient's age, gender, education level, socioeconomic level, height, weight, the duration of insulin use, who implemented the insulin treatment, whether the insulin treatment was regular, the existence of any chronic complications, existence of any other chronic diseases and how the patient felt when diagnosed with diabetes. This form was prepared by the researcher in line with the literature..$^{[5,8,17,21]}$

Insulin Treatment Appraisal Scale: ITAS was developed by Snoek et al. ${ }^{[22]}$ and its validity and reliability study was carried out by Surucu et al. ${ }^{[5]}$ in Turkey. ITAS is a 5-item Likert-type scale with 20 items. The rating scale was designed as a Likert type scale with the options ranging from "strongly disagree" (1 point) to "strongly agree" (5 points). The scale consists of 2 subdimensions with 4 positive items $(3,8,17,19)$ and 16 negative items. When the scale is scored, positive items are scored in reverse. The sum of the four positively expressed items (4-20) provides the positive evaluation sub-dimension while the sum of 16 negatively expressed items (16-80) provides the negative evaluation sub-dimension. Total scale score is obtained by adding the 16 items with negative expressions and the four items with positive expressions after they are reversed. The total of all the items (20 items) provides the total score (20100). The scale has no cut-off point. A high positive evaluation score indicates a high positive appraisal towards insulin, while a high negative evaluation score indicates a negative perception of insulin use. ${ }^{[5,22]}$ The internal consistency analysis of the scale 
(Cronbach's Alpha) was found to be 0.905 in our study and 0.80 in Surucu et al. ${ }^{[5]}$

Diabetes Self-Management Questionnaire (DSMQ): DSMQ was developed by Schmitt et al. ${ }^{[23]}$ in 2013 and the validity and reliability study of the scale was carried out by Eroğlu and Sabuncu ${ }^{[17]}$ in Turkey. The scale is a 4-point Likert type scale with 16 items. The rating scale was designed as a Likert type scale with the options ranging from "does not apply to me all" (0 points) to "applies to me very much" (3 points). The scale consists of 4 sub-dimensions: Glucose Management (GM), Dietary Control (DC), Physical Activity (PA) and Healthcare Use (HU). In DSMQ, 7 items are calculated as they are and 9 items are calculated in reverse (Item total score obtained from the total scale or sub-dimension) /(Maximum item total score that can be obtained from the total scale or sub-dimension) $\times 10$ ) For unanswered questions, 3 points are subtracted from the maximum item total score that can be obtained from the total scale or sub-dimension. A minimum of 0 and a maximum of 10 points can be obtained from the scale. If an item is omitted, it is evaluated as -3 points. As the score gets closer to 10, diabetes self-management increases. ${ }^{[17,23]}$ Internal consistency analysis of the scale (Cronbach's Alpha) was found 0.899 in our study and 0.85 in Eroğlu and Sabuncu. ${ }^{[17]}$

Ethical Declarations: To ensure compliance with ethical principles, written permission for non-interventional clinical research was obtained from the ethics committee (12/10/202090/72) and the institution (Number=E-44021967-605.01) where the study was conducted. The patients who were included in the study were informed about the study and their written permission to participate in the study was obtained. Written permission was obtained from authors, who conducted the Turkish validity and reliability study to use the scale in the study.

Data Analysis: The study data were analyzed with the SPSS 20.0 statistical program. Mean, standard deviation, numberpercentage distributions were used to evaluate the descriptive characteristics of the patients. The Kolmogorov-Smirnov test was used to analyze whether the data were suitable for normal distribution. Spearman's Correlation Analysis was performed for correlation analysis. Mann Whitney $U$ test and Kruskal Wallis test were used to evaluate the difference between ITAS and DSMQ mean scores according to independent variables. $P$ values $<0.05$ were considered significant.

\section{RESULTS}

The mean age of the patients included in the study was $44.57 \pm 14.8$. $52 \%$ were women, $72 \%$ were single, $47 \%$ were primary school graduates, $52 \%$ had a chronic disease other than T2DM, and $51 \%$ had a chronic complication related to T2DM. The mean body mass index (BMI) of the patients was $23.31 \pm 3.04 \mathrm{~kg} / \mathrm{m} 2$. The mean duration of insulin use was $2.8 \pm 1.17$ years (range $1-4$ ). It was found that $71 \%$ of the patients administered insulin on their own and $68 \%$ did not apply insulin regularly (Table 1).
Table 1. Distribution of the participants according to their sociodemographic and insulin usage characteristics ( $\mathrm{n}=100)$

\begin{tabular}{|c|c|c|}
\hline & $\mathbf{n}$ & $\%$ \\
\hline Age $(M \pm S D)$ & \multicolumn{2}{|c|}{$44.57 \pm 14.84(20-78)$} \\
\hline $\mathrm{BMI}(\mathrm{kg} / \mathrm{m} 2)(\mathrm{M} \pm \mathrm{SD})$ & \multicolumn{2}{|c|}{$23.31 \pm 3.04(17-34)$} \\
\hline \multicolumn{3}{|l|}{ Gender } \\
\hline Female & 52 & 52 \\
\hline Male & 48 & 48 \\
\hline \multicolumn{3}{|l|}{ Marital status } \\
\hline Single & 28 & 28 \\
\hline Married & 72 & 72 \\
\hline \multicolumn{3}{|l|}{ Education level } \\
\hline Primary school & 47 & 47 \\
\hline High school & 36 & 36 \\
\hline University & 17 & 17 \\
\hline \multicolumn{3}{|l|}{ Complication } \\
\hline Yes & 51 & 51 \\
\hline No & 49 & 49 \\
\hline \multicolumn{3}{|l|}{ Chronic disease } \\
\hline Yes & 52 & 52 \\
\hline No & 48 & 48 \\
\hline \multicolumn{3}{|l|}{ Administering insulin } \\
\hline Itself & 71 & 71 \\
\hline Family & 14 & 14 \\
\hline Other & 15 & 15 \\
\hline \multicolumn{3}{|l|}{ Regular use of insülin } \\
\hline Yes & 32 & 32 \\
\hline No & 68 & 68 \\
\hline Insulin duration (years) $(\mathrm{M} \pm \mathrm{SD})$ & \multicolumn{2}{|c|}{$2.8 \pm 1.17(1-4)$} \\
\hline
\end{tabular}

Patients' mean DSMQ total score was $4.07 \pm 1.74$ (range 0.628.75). Table 2 presents the mean scores of the sub-dimensions. Patients'ITAS positive and negative item subscale mean scores were $12.56 \pm 3.43$ and $48.18 \pm 12.09$, respectively (Table 2 ).

\begin{tabular}{lcccc}
$\begin{array}{l}\text { Table 2. Patients' DSMQ and ITAS total and sub-dimension mean scores } \\
(\mathrm{n}=100)\end{array}$ & M & SD & Min & Max \\
\hline & & & & \\
\hline DSMQ & 3.62 & 2.63 & 0 & 10 \\
GM & 4.21 & 2.44 & 0 & 10 \\
DC & 4.42 & 2.52 & 0 & 8.89 \\
FA & 1.42 & 1.11 & 7.78 \\
HU & 4.41 & 1.74 & 0.62 & 8.75 \\
Total & 4.07 & & & \\
ITAS & 12.56 & 3.43 & 4 & 19 \\
Positive & 48.18 & 12.09 & 24 & 65 \\
Negative & 48.19 \\
\hline $\begin{array}{l}\text { Note. DSMQ= Diabetes Self-Management Questionnaire, GM=Glucose Management, DC=Dietary } \\
\text { Control, PA=Physical Activity and HU=Healthcare Use, ITAS=Insulin Treatment Appraisal Scale, } \\
\text { M=Mean, SD=standard deviation }\end{array}$
\end{tabular}

There was no significant difference between DSMQ and ITAS total and subscale scores according to age and gender $(p>0.05)$. University graduate patients had higher DSMQ total and subscale scores compared to the primary and high school graduates $(p<0.001)$. It was found that total DSMQ total and all 
subscale mean scores of the married patients were higher and lower ITAS negative item mean score compared to the scores of the single patients $(p<0.001)$. DSMQ total and all subscale mean scores and ITAS positive item subscale scores of the patients with complications were statistically significantly higher compared to those without complications $(p<0.05)$. Patients with chronic disease had higher DSMQ total and all subscale and ITAS positive item scores compared to the patients without chronic disease $(p<0.001)$. ITAS positive item sub-dimension mean scores were found to be high while ITAS negative item sub-dimension was found to be lower in patients who regularly used insulin compared to those who did not use it regularly $(p<0.001)$. It was found that DSMQ total and GM, DC, HU subscale scores of patients who used insulin regularly were higher than those who did not have regular use $(p<0.001)$ (Table 3).

Table 3. DSMQ and ITAS Total and Sub-Dimensional Scores by Independent Variables

\begin{tabular}{|c|c|c|c|c|c|c|c|c|c|c|}
\hline & \multicolumn{10}{|c|}{ DSMQ } \\
\hline & \multicolumn{2}{|c|}{ GM } & \multicolumn{2}{|r|}{ DM } & \multicolumn{2}{|c|}{ FA } & \multicolumn{2}{|c|}{ HU } & \multicolumn{2}{|c|}{ Total scale } \\
\hline & Median & $\mathrm{M} \pm \mathrm{Sd}$ & Median & $\mathrm{X}^{-} \pm \mathrm{Ss}$ & Median & Median & $\mathrm{X}^{-} \pm \mathrm{Ss}$ & $\mathrm{X}^{-} \pm \mathrm{Ss}$ & Median & $\mathrm{X}^{-} \pm \mathrm{Ss}$ \\
\hline \multicolumn{11}{|l|}{ Education level } \\
\hline Primary school & 63.16 & $4.5 \pm 2.42$ & 63.86 & $5.23 \pm 2.05$ & 38.09 & $3.33 \pm 1.75$ & 63.26 & $5.01 \pm 1.24$ & 61.24 & $4.56 \pm 1.48$ \\
\hline High school & 47.07 & $3.43 \pm 2.72$ & 46.57 & $3.98 \pm 2.43$ & 62.76 & $5.49 \pm 2.27$ & 45.51 & $4.2 \pm 1.38$ & 50.21 & $4.13 \pm 1.85$ \\
\hline \multirow[t]{2}{*}{ University } & 22.76 & $1.61 \pm 1.8$ & 21.88 & $1.86 \pm 1.68$ & 58.85 & $5.16 \pm 3.53$ & 25.79 & $3.2 \pm 1.03$ & 21.41 & $2.56 \pm 1.33$ \\
\hline & \multicolumn{2}{|c|}{$x 2=25.364 p<0.001$} & \multicolumn{2}{|c|}{$x 2=27.831, p<0.001$} & \multicolumn{2}{|c|}{$x 2=18.407, p<0.001$} & \multicolumn{2}{|c|}{$x 2=24.167, p<0.001$} & \multicolumn{2}{|c|}{$x 2=23.631, p<0.001$} \\
\hline \multicolumn{11}{|l|}{ Marital status } \\
\hline Married & 60.9 & $4.44 \pm 2.62$ & 61.98 & $5.14 \pm 2.14$ & 61.25 & $5.4 \pm 3.25$ & 60.17 & $4.88 \pm 1.3$ & 60.98 & $4.63 \pm 1.63$ \\
\hline \multirow[t]{2}{*}{ Single } & 23.77 & $1.52 \pm 1.02$ & 20.98 & $1.82 \pm 1.24$ & 46.32 & $4.04 \pm 2.07$ & 25.62 & $3.21 \pm 0.92$ & 23.55 & $2.63 \pm 1.02$ \\
\hline & \multicolumn{2}{|c|}{$Z=-5.789, p<0.001$} & \multicolumn{2}{|c|}{$Z=-6.421, p<0.001$} & \multicolumn{2}{|c|}{$Z=-2.444, p<0.001$} & \multicolumn{2}{|c|}{$Z=-5.544, p<0.001$} & $Z=-5$ & $p<0.001$ \\
\hline Complication & & & & & & & & & & \\
\hline Yes & 56.71 & $3.8 \pm 1.98$ & 58.69 & $4.75 \pm 1.95$ & 66.36 & $5.83 \pm 2.6$ & 63.15 & $4.97 \pm 1.16$ & 55.52 & $4.13 \pm 1.17$ \\
\hline No & 44.04 & $3.43 \pm 3.18$ & 41.98 & $3.64 \pm 2.78$ & 35.26 & $3.07 \pm 1.52$ & 37.34 & $3.83 \pm 1.44$ & 45.28 & $4 \pm 2.19$ \\
\hline & $Z=-2.19$ & $9, P=0.028$ & $Z=-2$ & $3, P=0.004$ & $Z=-5.6$ & $p<0.001$ & $Z=-4$ & $p<0.001$ & $Z=-1$. & $p=0.077$ \\
\hline Chronic disease & & & & & & & & & & \\
\hline Yes & 59.8 & $4.21 \pm 2.4$ & 60.88 & $4.98 \pm 2.08$ & 63.03 & $5.53 \pm 2.69$ & 64.1 & $5.02 \pm 1.74$ & 59.3 & $4.41 \pm 1.46$ \\
\hline No & 40.43 & $2.99 \pm 2.74$ & 39.26 & $3.37 \pm 2.54$ & 38.93 & $3.4 \pm 1.85$ & 35.77 & $3.75 \pm 1.37$ & 40.97 & $3.7 \pm 1.95$ \\
\hline & $Z=-3.36$ & $1, p=0.001$ & $Z=-3$. & $7, p=0.004$ & $Z=-4.3$ & $p<0.001$ & $Z=-5$ & $p<0.001$ & $Z=-3$. & $p=0.002$ \\
\hline Regular use of ins & & & & & & & & & & \\
\hline Yes & 82.89 & $6.60 \pm 2.22$ & 82.48 & $6.93 \pm 1.46$ & 53.4 & $4.66 \pm 2.58$ & 66.39 & $5.21 \pm 1.37$ & 80.11 & $5.85 \pm 1.53$ \\
\hline No & 35.26 & $2.22 \pm 1.3$ & 35.45 & $2.93 \pm 1.63$ & 44.33 & $3.92 \pm 2.33$ & 43.02 & $4.04 \pm 1.29$ & 36.57 & $3.23 \pm 1.06$ \\
\hline & $Z=-7.71$ & $6, p<0.001$ & $Z=-7$. & $4, p<0.001$ & $Z=-1.5$ & $p=0.123$ & $Z=-3$. & $p<0.001$ & $Z=-7.0$ & $p=<0.001$ \\
\hline & & & & TAS & & & & & & \\
\hline & & itive & & gative & & tal & & & & \\
\hline & Median & $\mathrm{X}^{-} \pm$Ss & Median & $\mathrm{X}^{-} \pm$Ss & Median & $\mathrm{X}^{-} \pm \mathrm{Ss}$ & & & & \\
\hline Education level & & & & & & & & & & \\
\hline Primary school & 57.72 & $13.43 \pm 3.65$ & 43.29 & $44.21 \pm 12.94$ & 47.6 & $57.64 \pm 15.92$ & & & & \\
\hline High school & 43.67 & $11.72 \pm 3.65$ & 55.4 & $50.72 \pm 11.43$ & 52.4 & $62.44 \pm 14.52$ & & & & \\
\hline University & 45 & $11.94 \pm 0.97$ & 60.06 & $53.76 \pm 6.56$ & 54.5 & $65.71 \pm 7.24$ & & & & \\
\hline & $x 2=5.6$ & $9, p=0.06$ & $\times 2=5$. & $97, p=0.055$ & $x 2=0$ & $p=0.622$ & & & & \\
\hline Marital status & & & & & & & & & & \\
\hline Married & 51.51 & $12.69 \pm 3.95$ & 43.83 & $45.19 \pm 12.83$ & 46.28 & $57.89 \pm 15.96$ & & & & \\
\hline Single & 47.89 & $12.21 \pm 1.37$ & 67.66 & $55.86 \pm 4.27$ & 61.34 & $68.07 \pm 5.05$ & & & & \\
\hline & $Z=-0.5$ & $5, p=.572$ & $Z=-3$. & $5, p<0.001$ & $Z=-2$. & $2, p=0.02$ & & & & \\
\hline Complication & & & & & & & & & & \\
\hline Yes & 66.82 & $14.53 \pm 3.02$ & 50.29 & $47.31 \pm 12.27$ & 55.63 & $61.84 \pm 14.87$ & & & & \\
\hline No & 33.51 & $10.51 \pm 2.51$ & 50.71 & $49.08 \pm 11.96$ & 45.16 & $59.59 \pm 14.2$ & & & & \\
\hline & $Z=-5.7$ & $p<0.001$ & $Z=-0$. & $3, p=0.942$ & $Z=-1 . \varepsilon$ & $p=0.071$ & & & & \\
\hline Chronic disease & & & & & & & & & & \\
\hline Yes & 60.74 & $13.81 \pm 3.69$ & 47.47 & $45.92 \pm 12.96$ & 51.8 & $59.73 \pm 16.09$ & & & & \\
\hline No & 39.41 & $11.21 \pm 2.53$ & 53.78 & $50.63 \pm 10.67$ & 49.09 & $61.83 \pm 12.67$ & & & & \\
\hline & $Z=-3.7 C$ & $6, p<0.001$ & $Z=-1$. & $38, p=0.276$ & $Z=-0$. & $p=0.641$ & & & & \\
\hline Regular use of ins & & & & & & & & & & \\
\hline Yes & 30.22 & $9.88 \pm 2.93$ & 16.5 & $31.69 \pm 3.86$ & 16.5 & $41.56 \pm 5.98$ & & & & \\
\hline No & 60.04 & $13.82 \pm 2.89$ & 66.5 & $55.94 \pm 4.25$ & 66.5 & $69.76 \pm 6.04$ & & & & \\
\hline & $Z=-4.83$ & $p=<0.001$ & $Z=-8.0$ & $2, p=<0.001$ & $Z=-8.0$ & $p=<0.001$ & & & & \\
\hline
\end{tabular}


The relationship between patients' DSMQ sub-dimensions and ITAS positive and negative item sub-dimensions was evaluated with Spearman's Correlation Analysis. A weak positive significant relationship was found between the GM, DC, FA sub-dimensions and the ITAS positive item subdimension $(p<0.005)$. A strong negative significant correlation was found between the GM, DC sub-dimension and the ITAS positive item sub-dimension $(p<0.005)$ (Table 4$)$.

\begin{tabular}{lcccc} 
Table 4. Correlation between DSMQ and ITAS \\
\cline { 2 - 5 } DSMQ & \multicolumn{4}{c}{ Positive } \\
\cline { 2 - 5 } & $\mathbf{r}$ & $\mathbf{p}$ & $\mathbf{r}$ & $\mathbf{p}$ \\
\hline ITAS & \multicolumn{4}{c}{ Negative } \\
GM & $0.394^{* *}$ & $\mathrm{p}<0.001$ & $-0.709^{* *}$ & $\mathrm{p}<0.001$ \\
DC & $0.322^{* *}$ & .001 & $-0.723^{* *}$ & $\mathrm{p}<0.001$ \\
FA & $0.29^{* *}$ & .003 & -0.17 & .866 \\
HU & 0.051 & .616 & -0.23 & .021 \\
\hline
\end{tabular}

Note. $\mathrm{DSMQ}=$ Diabetes Self-Management Questionnaire, $\mathrm{GM}=$ Glucose Management, $\mathrm{DC}=$ Dietary Control, PA=Physical Activity and $\mathrm{HU}=$ Healthcare Use, ITAS=Insulin Treatment Appraisal Scale, Correlation is significant at the 0.01 level

\section{DISCUSSION}

Type 2 Diabetes Mellitus, one of the most common types of diabetes in society, usually occurs after the age of 40 and its incidence increases with aging. The disease is reported to be more common among women in developing countries while there is no difference in the rate of incidence in terms of gender in developed countries. ${ }^{[2,24]}$ In this study, the mean age of the patients was $44.57 \pm 14.8$ and $52 \%$ of them were women. National and international studies in the field report the mean age of the patients as over 50 with varying ratios for men and women. ${ }^{[5,8,20,21,23,25-28]}$ In this study, the mean age was found to somewhat younger compared to the literature. T2DM is more prevalent when accompanied by obesity. Prevalence of diabetes in obese people is at least twice as high compared to non-obese people. ${ }^{[24,28]}$ The patients in this study were in the normal weight category with an average BMI of 23. Previous studies demonstrated that diabetic patients are generally in the category of slightly overweight and obese..$^{[5,17,20,22,26]}$ The mean BMI may be lower in this study compared to other studies in the literature due to the young age of the patients.

Diabetes managementis based on the patient's self-assessment of diabetes care outcomes. Diabetes management includes nutritional therapy, regular exercise, blood glucose control, medication and education management and compliance with these parameters. ${ }^{[3,17,24]}$ In this study, patients' mean DSMQ score was found to be $4.07 \pm 1.74$. Accordingly, these patients' diabetes self- efficacy was below the average. dabetes selfmanagement was found to be below the intermediate level. When the literature is reviewed, it is seen that there are studies supporting our study results. ${ }^{[26,29]}$ Another important point in diabetes management is the compliance of the patients with the treatment plan that includes diet, exercise and medical applications. ${ }^{[30,31]}$ In this study, patients' self-management in regards to glucose management, diet control, physical activity and the use of health services was also found to be low. Previous studies in the field determined that 50\%, $71.7 \%$, and $37 \%$ of the patients complied with their treatment. ${ }^{[30,32]}$ Other national studies reported that patients had a low rate of exercise, did not pay attention to their diet, had a low rate for visiting the doctor and had high rates of experiencing hyperglycemia or hypoglycemia. ${ }^{[25,31]}$

In type 2 diabetes, insulin treatment starts in cases where acute and chronic complications occur, glycemic control is impaired due to various reasons, and glycosuria accompanies hyperglycemia. ${ }^{[33]}$ Insulin treatment is initiated in approximately half of the patients with type 2 diabetes in approximately 5 years after the diagnosis. ${ }^{[8]}$ In this study, the mean duration of insulin use was found to be approximately 3 years. In Holmes eat al. ${ }^{[26]}$ and Snoek et al. ${ }^{[22]}$, the mean duration for starting insulin treatment was found to be 4.1 and 5.3 years, respectively. Although it is known that approximately half of the diabetes patients in the world need insulin treatment, it is argued that the patients do not take insulin in sufficient amounts. ${ }^{[5,9]}$ In this study, patients' positive perception towards insulin treatment was moderate. While there are other studies in literature that identified lower positive perception scores than this study, ${ }^{[5,8]}$ there are also other studies with similar or higher positive perception scores. $[20,26,27]$ In addition, as a result of our study, it can be argued that patients' negative perception towards insulin treatment was high. Negative insulin assessment is common among T2DM adults. ${ }^{[26]}$ It is seen that there are studies in the literature that support our study results. However, unlike our study, Ozden et al (2019) found lower negative perception scores (17.4) towards insulin. ${ }^{[34]}$

Self-efficacy is a significant predictor of negative insulin treatment perception in patients with type 2 diabetes. [8] This study also found a highly significant negative correlation between the GM and DC sub-dimensions of the diabetes self-management scale and negative insulin perception. Accordingly, it is concluded that the negative insulin perception is high in patients with high GM and DC management in diabetes. Similarly, Holmes et al. ${ }^{[26]}$ and Sürücü and Samancıoğlu ${ }^{[8]}$ also determined that those with more negative insulin appraisals had a decrease in diabetes self-efficacy.

Acute or long-term complications can be observed in diabetes as a result of uncontrolled blood glucose levels. Half of the patients $(51 \%)$ in this study reported having a chronic complication. In other studies, it is seen that the rates of complications related to diabetes are similar. ${ }^{[5,8,17,26]}$ Preventing possible diabetes complications is crucial to reduce the burden on the people and the community. ${ }^{[1,3]}$ Hence, individuals with diabetes need to acquire self-management skills. ${ }^{[24]}$ In our study, it was determined that patients with complications had better self-efficacy and positive perception towards insulin. It is known that the incidence of complications is high in people with poor diabetes self-management and insulin 
perception. ${ }^{[17,26,29]}$ However, this result of our study shows that individuals with complications may have gained more selfefficacy and created a better perception for the management of complications. Unlike our study, in the study of Yanık and Erol, ${ }^{[29]}$ no statistical significance was found between the presence of chronic complications and the level of self-efficacy for diabetes. In our study, it was also found that those with different chronic diseases have better self-management and perception of insulin. A chronic disease other than diabetes increases the risk of complications. ${ }^{[24]}$ These individuals may have gained better self-management to reduce the risk of complications.

As the level of education raises awareness, patients focus more on the symptoms of their illness. In addition, their belief that they can cope with their diseases with appropriate treatment and disease control is increasing. ${ }^{[35]}$ Therefore, patients with a higher education level can be expected to have a higher self-efficacy. In the literature, there are studies reporting that diabetes self-efficacy increases as the education level of individuals increases. ${ }^{[29,36]}$ The finding in our study, unlike the literature, is that patients with higher education levels have lower diabetes selfefficacy. This finding shows that, contrary to expectations, people's belief that they can manage their illness well is not related to education level. In addition, it is thought that some sociodemographic and clinical characteristics such as diabetes duration and education about diabetes also affect this relationship.

The primary helpers of people with diabetes in diabetes management are their families and relatives. ${ }^{[39,40]}$ In our study, it was found that married patients have higher selfmanagement and lower negative perception towards insulin. This finding shows the importance of family support on diabetes management and insulin perception, which is also mentioned in the literature. ${ }^{[38,39]}$ However, unlike our study, Sürücü and Samancıoğlu (2018) determined that living alone reduces negative perception towards insulin therapy ${ }_{.}^{[8]}$ Also, there are studies reporting that marital status is not effective in terms of diabetes management and insulin perception. . $^{[25,26,29,36]}$

It has been reported that patients who use insulin regularly have high positive perceptions of insulin treatment and have low negative perceptions as well as high levels of diabetes self-management. Effective diabetes management requires behavioral adaptation. Individuals' level of compliance to treatment and their attitudes towards diabetes are two factors that affect each other positively. ${ }^{[36]}$ This study determined that patients using insulin regularly, that is, adapting to insulin treatment, increased their positive evaluation of insulin, decreased their negative evaluation and that attitude positively affected their self-care. Therefore, awareness should be raised about the regular use of insulin in individuals with diabetes through education, etc., and patients should be encouraged to use insulin regularly.

\section{CONCLUSION}

Our study results show that patients' diabetes selfmanagement or perception of insülin is low. Nurses can contribute to the participation of patients using insulin in diabetes management and to create a positive insulin perception. For this, it can be suggested that the continuity of patient and nurse interaction and that nurses use their trainer and consultancy roles effectively. In addition, our study revealed that patients with diabetes-related complications and another chronic disease have poor self-management and insulin perception. Therefore, planned and regular training on disease management is needed especially for these patient groups. It may be suggested that the education be continued with home visits after discharge. It is recommended to conduct long-term follow-up studies with larger samples in order to determine the effect of planned training on selfmanagement. In addition, it is recommended to replicate the study in diabetic individuals receiving treatment in services and outpatient clinics. Also, different studies can be conducted with samples comprised of Type 1 diabetes patients.

\section{ETHICAL DECLARATIONS}

Ethics Committee Approval: This study was approved by Izmir Bakircay University Non-interventional Clinical Research Ethics committee (Date: 12/10/2020, Decision No: 90/72).

Informed Consent: All patients signed the free and informed consent form.

Referee Evaluation Process: Externally peer-reviewed.

Conflict of Interest Statement: The authors have no conflicts of interest to declare.

Financial Disclosure: The authors declared that this study has received no financial support.

Author Contributions: All of the authors declare that they have all participated in the design, execution, and analysis of the paper, and that they have approved the final version.

\section{REFERENCES}

1. Diabetesatlas.org [homepage on the Internet]. IDF Diabetes Atlas (9th ed), Brussels, Belgium [updated 2019; cited 01 March 2021]. Available from:http://www.diabetesatlas.org

2. American Diabetes Association. ADA Classification And Diagnosis Of Diabetes. Diabetes Care 2017;40(1):11-24.

3. Clinical Practice Guideline for Diagnosis,Treatment and Follow-up of Diabetes Mellitus and Its Complications. The Society Of Endocrinology And Metabolism of Turkey. English Version of the 12th ed. Ankara;2019. p.23

4. Saeedi $P$, Salpea $P$, Karuranga $S$ et al. Mortality attributable to diabetes in 20-79 years old adults, 2019 estimates:Results from the International Diabetes Federation Diabetes Atlas. Diabetes Res Clin Pract 2020;162:108086.

5. Surucu HA, Baksi A, Samancioğlu S. Validity and reliability of the turkish version of insulin treatment appraisal scale for type 2 diabetes patients. Int. J. Caring Sci 2017;10(3):1187-200.

6. Sofulu F, Avdal EÜ. The effect of family support and family conflict on the self-management process in type 2 diabetes. Nurs Forum on Diabetes, Obesity, and Hypertension 2016;8(2):15-8. 
7. American Diabetes Association. ADA. Standards of Medical Care in Diabetes . Diabetes Care 2014;37(1):14-80.

8. Sürücü HA, Samancıoğlu S. Predictors of Negative Insulin Treatment Perception in Type 2 Diabetes Individuals. TurkiyeKlinikleri J Nurs Sci 2018;10(2):130-7.

9. Nathan DM. Realising the long-term promise of insulin therapy:the DCCT/ EDIC study. Diabetologia 2021;64:1049-58.

10. Matuszewski W, Baranowska-Jurkun A, Stefanowicz-Rutkowska MM, Gontarz-Nowak K, Gątarska E, Bandurska-Stankiewicz E. The safety of pharmacological and surgical treatment of diabetes in patients with diabetic retinopathy-A Review. J. Clin. Med 2021;10(4):705.

11. Song $Y$, Jeon $Y$, Cho J, et al. Development of a psychological insulin resistance scale for Korean patients with diabetes. J Korean Acad Nurs 2016;46:813-23.

12. Song Y, Ku BJ, Cho J, Jun Y, Kim B, Nam S. The prevalence of insulin refusal and psychological insulin resistance among Korean patients with type 2 diabetes mellitus. Ann Transl Med 2019;7(23):760.

13. Saleem A, Masood I, Khan TM, et al. Insulin perception among insulin-refusal type-2 diabetes mellitus patients in Pakistan. Cogent Med 2016;3:1229374

14. Polat HB, Çeliker M, Özyurt S, Terzi S, Özgür A. Insulin resistance and affecting factors in patients with obstructive sleep apnea syndrome. Int J Otorhinolaryngol Head Neck Surg 2017;3(4):986-9.

15. Torabian F, Mostafavian Z, Ghareh S, Yazdi MS, Khazaei MR. Data on insulin therapy refusal among type II diabetes mellitus patients in Mashhad, Iran. Data Brief 2018;18:2047-50.

16. Aleali AM, Payami SP, Latifi SM, Yazdanpanah L, Hesam S, Khajeddin N. Evaluation of psychological resistance to insulin treatment in type II diabetic patients. Diabetes Metab Syndr 2018;12(6):929-32.

17. Eroğlu N, Sabuncu N. Adaptation of Diabetes Self-Management Scale (DSMQ) to Turkish Society:Validity and Reliability Study. Journal of Nursing Science 2018;1(3):1-6.

18. He X, Li J, Wang B, et al. Diabetes self-management education reduces risk of all-cause mortality in type 2 diabetes patients:a systematic review and meta-analysis. Endocrine 2017;55(3):712-31.

19. Powers MA, Bardsley J, Cypress M, et al. Diabetes self-management education and support in type 2 diabetes:a joint position statement of the american diabetes association, the american association of diabetes educators, and the academy of nutrition and dietetics. The Science Diabetes Self-Manag Care 2017;43(1):40-53.

20. Chen CC, Li TC, Huang CY, Chang MP. Validation of the Chinese version of the insülin treatment appraisal scale. Diabetes Res Clin Pract 2020;170:17.

21. Lee KP. Validity and reliability of the Chinese version ofthe Insulin Treatment Appraisal Scale among primary care patients in Hong Kong. Hong Kong Med J 2016;22:306-13.

22. Snoek FJ, Skovlund SE, Pouwer F. Development and validation of the insulin treatment appraisal scale (ITAS) in patients with type 2 diabetes. Health Qual. Life Outcomes 2007;5(5):69-75.

23.Schmitt A, Hermanns N, Kulzer B. The Diabetes Self-Management Questionnaire (DSMQ):Development and evaluation of an instrument to assess diabetes self-care activities associated with glycaemic control. Health Qual. Life Outcomes 2013;11(1):138-51.

24. Karadakovan A, Aslan FE. Care in Internal and Surgical Diseases. 5th ed. Academician Bookstore:Ankara;2020. p.787.

25. Rashidi M, Genç A. Evaluation of Diabetes Attitudes of Patients with Type 1 and Type 2 Diabetes. Igusabder 2020;10:34-49.

26. Holmes-Truscott E, Browne JL, Ventura AL, Pouwer F, Speight J. Short Report:Educational and Psychological Aspects Diabetes stigma is associated with negative treatment appraisals among adults with insulin-treated Type 2 diabetes:results from the second Diabetes MILES Australia (MILES-2) survey. Diabetic Med 2018;35(5):658-62.

27. Lee KP. Translation and validation of the Insulin Treatment Appraisal Scale in Hong Kong primary care patients. J Diabetes Investig 2018;9:311-20.

28. Sandouk Z, Lansang MC. Diabetes with obesity--Is there an ideal diet? Cleve Clin J Med 2017;84(7 Suppl 1):4-14.
29. Yanık YT, Erol Ö. Evaluation of self-efficacy levels of ındividuals with type 2 diabetes. Anatolian Journal of Nursing and Health Sciences 2016;19(3):166-74.

30. Kartal A, Çağırgan G, Tığlı H, Güngör Y, Karakuş N, Gelen M. The attitudes and attitudes of patients with type 2 diabetes towards care and treatment and the factors affecting the attitude. TSK Preventive Medicine Bulletin 2008;7(3):223-30.

31. Çalık A, Kapucu S. Developing Healthy Lifestyle Behaviors in Diabetic Patients:Pender's Health Promotion Model. Hacettepe University Nursing Faculty Journal 2017;4(2):62-75.

32. Beyazıt E, Mollaoğlu M. Investigation of effect on glycosylated hemoglobin, blood pressure, and body mass index of diabetes intensive education program in patients with type 2 diabetes mellitus. American Journal of Men's Health 2011;5(4):351-7.

33. Turan E, Kulaksızoğlu M. Current approaches in the treatment of type 2 diabetes. Okmeydanı Medical Journal 2015;31:86-94.

34. Özden G, Çevik S, Sarıtaş SÇ. Discomfort endurance capacity in $\mathrm{dm}$ patients and perspective on insulin therapy. II International Battalgazi Multidisciplinary Studies Congress:Malatya;2019.

35. Yorulmaz H, Tatar A, Saltukoğlu G, Soylu G. Analysis of the factors Influencing Illness perception in patients with diabetes. FSM Journal of Humanities and Social Sciences 2013;2:367-87.

36. Ustaalioğlu S, Tan M. Investigation of type 2 diabetes patients' attitudes and behaviors towards care and treatment. Gümüşhane University Journal of Health Sciences. 2017;6(4):12-20.

37. Baykal $D$, Orak $E$. The Investigation of the family effect on glycemic control of type 2 diabetes mellitus patients. IGUSABDER 2018;4:361-82

38. Sofulu F, Ünsal Avdal E. The affect to self-management process of family support or conflict at the diabetes type 2. Journal of the Nurs Forum in Diabetes, Obesity and Hypertension 2016;8:15-8 